\title{
A history of IAU Commission C1: a look from the Newsletters
}

\author{
Paulo S. Bretones \\ DME, São Carlos Federal University (UFSCar) \\ Caixa Postal 676, CEP 13565-905 - São Carlos, SP, Brazil \\ email: bretones@ufscar.br
}

\begin{abstract}
This work aims to present the partial results of a project to collect and analyze all the issues of the Newsletters of Commission C1 (Astronomy Education and Development), formerly named Commission 46. The sources and the (hard) work to obtain printed editions, digitalize and make them available on the Internet are shown. Over 40 years, 86 issues from 1977 until 2017 were published. The Newsletters list the structure of the Commission featuring the names of presidents, vice-presidents, organizing committee, editors, printing and distribution responsible with editorial and presidential letters in the cover. A preliminary analysis of contents of the published material is done. The results present the main subjects of stories that were related to papers, teaching materials, book reviews, courses and meetings. Many solar eclipses and other phenomena were reported. Reports of important projects of the commission were published, such as: International Schools for Young Astronomers (ISYAs), the travelling telescope among others WG projects. Stories of travels and triennial reports from many countries were continuously published presenting many actions and activities for all school levels, non-school activities such as planetariums and many other astronomy subjects. Reports of the education sessions and business meetings held during the IAU GAs and projects in developing countries complemented these publications. Occasionally, papers dealing with great questions and subjects can be found. There are many published contributions that show the participation of many members from many countries and the efforts to improve the astronomy education throughout the world. The surveyed material can be very useful for the next generations of astronomy education researchers, practitioners and teachers, not only as a repository of historical documents, but also as an inspiration for future projects.
\end{abstract}

Keywords. Commission 46, Commission C1, Newsletters, History

\section{Introduction}

This work aims to present the partial results of a project to get all the issues of the Newsletters of Commission C1 (Astronomy Education and Development) of the International Astronomical Union (IAU), formerly named Commission 46, and make an initial analysis of the contents.

Over 40 years, 86 issues from 1977 until 2017 were published. However, only 47 issues were available on the Commission Website. Therefore, the initial task was to obtain the 39 missing issues and for this, which was quite a lot of hard work to perform. The first group was from my own archives with issues that I got by mail years ago from D. Wentzel, L. Gouguenheim and J. Percy (18 issues). Then after many contacts with institutions, past presidents and editors, and obtaining other pdfs from Michèle Gerbaldi (IAP, France), I acquired 16 issues, and from Eric McKenzie (University of Maryland): 5 issues. Unfortunately, I could not obtain the Newsletters 12, 23, 24, 24B or 25.

Next, the print editions were digitized and I made them available on the Internet at (http://iaucc1.frm.utn.edu.ar) and eventually at the Div. C/Com. C1 website. 
Table 1. Years, Presidents and Editors of the NL

\begin{tabular}{lll}
\hline Years & President & Editor \\
\hline $1967-1970$ & E. Schatzman & \\
$1970-1973$ & E. A. Müller & \\
$1973-1976$ & D. McNally & Derek McNally N.1-18 (June 77 to Sept 85) \\
$1976-1979$ & E. Kononovich & \\
$1979-1982$ & D. G. Wentzel & \\
$1982-1985$ & L. Houziaux & John Percy N.19-48 (Feb 86 to Spring 98) \\
$1985-1988$ & C. Iwaniszewska & \\
$1988-1991$ & A. Sandqvist & \\
$1991-1994$ & L. Gouguenheim & \\
$1994-1997$ & J. Percy & \\
$1997-2000$ & J. Fierro & \\
$2000-2003$ & S. Isobe & \\
$2003-2006$ & J. Pasachoff & \\
$2006-2009$ & M. Stavinschi & \\
$2009-2012$ & R. M. Ros & Larry Marschall N.77-87 (Mar 2013 to May 2018) \\
$2012-2015$ & J.-P. De Greve & \\
$2015-2018$ & B. Garcia & \\
\hline
\end{tabular}

A few published papers (in other publications) discuss the history and projects of the Commission such as: Wentzel (1990a,b), Gerbaldi (1990) and Isobe (2005). However, in addition to these, the reading of the Newsletters should provide a wider study of the history of the Commission.

We note that this is a first study and does not intend to be complete or to use a very systematic approach to review the contents of the Newsletters (NL). It is only a contribution for the IAU S349 about the IAU history and humbly accounts for the great work of the Commission 46 (C1) throughout the decades. This preliminary analysis of the contents of the published material is done and shows some characteristics such as format, layout, covers, projects, reports, meetings, news, papers and structure of the Commission etc.

\section{The analysis}

As mentioned above, the structure of the Commission in the covers listed the names of presidents, vice-presidents, organizing committee, editors, printing and distribution responsible with editorial and letters from the commission president.

The first issue (NL1, June 1977) with eight pages was typed and published the Editorial, with Circular Letter no. 1, from the President of the Commission, E.V. Kononovich. It also included Corrections to the List of members of Commission 46, Recent Items in the News, papers on An Introductory Course in Astronomy (by D. McNally), a Letter from W.J. Bisard and an Update on Astronomy Education in USA. The cover is shown in Fig. 1.

The same cover layout was maintained until NL6, 1980. Other layout and formats were published as: NL 7, 1980 to NL 29, 1990 (Fig. 2); NL30, 1990 to NL34, 1992 (Fig. 3); NL35, 1992 to NL 48, 1998 (Fig. 4) and NL49, 1998 to NL87, 2018 (Fig. 5).

Commission 46 was founded in 1967, but only in 1977 started to publish the NL. During the years, the presidents and editors are shown in Table 1 . As can be seen, the editors held office for a variable number of years: D. McNally (8), J. Percy (12), B. Jones (14) and L. Marschall (5).

The results of the preliminary analysis of contents present the main subjects of matters related to the Commission Projects as: International School for Young Astronomers (ISYA); Visiting Lecturers Program (VLP); The Travelling Telescope (TT); National Reports; Astronomy Educational Materials; Meetings; Courses; Astronomical Phenomena; Papers; Projects and Issues and Book Reviews. 
Table 2. International School for Young Astronomers, years and NL reports

\begin{tabular}{cclccclc}
\hline N & year & country & NL, year & N & year & country & NL, year \\
\hline 1 & 1967 & UK & & 21 & 1994 & Egypt & 40,1994 \\
$(\ldots)$ & & & 22 & 1995 & Brazil & 43,1996 \\
8 & 1977 & Brazil & 2,1977 & 23 & 1997 & Iran & 51,1999 \\
$(\ldots)$ & & & 24 & 1999 & Romania & 59,2003 \\
15 & 1986 & Portugal & 21,1987 & $(\ldots)$ & & & \\
16 & 1989 & Cuba & 29,1990 & 29 & 2007 & Malaysia & 67,2007 \\
17 & 1990 & Malaysia & 30,1993 & $(\ldots)$ & & & \\
$(\ldots)$ & & & 35 & 2013 & Indonesia & 78,2013 \\
19 & 1992 & China & 36,1993 & $(\ldots)$ & & & \\
20 & 1994 & India & 39,1994 & 41 & 2018 & Colombia & \\
\hline
\end{tabular}

\begin{tabular}{|c|c|}
\hline \multicolumn{2}{|c|}{$\begin{array}{l}\text { INTERNATIONAL ASTRONOMICAL UNION } \\
\text { COMMISSION } 46 \text { - TEACHING OF ASTRON } \\
\text { NE W LETTER }\end{array}$} \\
\hline $\begin{array}{l}\text { President: } \\
\text { E. V. Kononovich } \\
\text { Sternbergh Astronomical } \\
\quad \text { Institute } \\
\text { Moscow University } \\
\text { Moscow. USSR 117234 } \\
\text { Vice-Presidents: } \\
\text { D. Wentze1 (Maryland) } \\
\text { L. Houziaux (Mons) } \\
\text { Organizing Committee: } \\
\text { W. Buscombe } \\
\text { J. Kleczek } \\
\text { D. McNally } \\
\text { L. Mavridis } \\
\text { B. Peery } \\
\text { M. Rigutti } \\
\text { A. Ringuelet } \\
\text { Editor: } \\
\text { D. McNa11y } \\
\text { aiversity of London } \\
\quad \text { Observatory } \\
\text { Mi11 Hil1 Park } \\
\text { London NW7 2QS } \\
\text { United Kingdom } \\
\text { Printing and distribution: } \\
\text { Astronomy Program } \\
\text { University of Maryland } \\
\text { College Park, MD } 20742 \\
\text { U.S.A. }\end{array}$ & $\begin{array}{l}\text { EDITORIAL. } \\
\text { Commission } 46 \text {, with this issue of its NEWSLETTER, } \\
\text { launches a new project aimed at providing a means of } \\
\text { communications between members of the commission and } \\
\text { others interested in the teaching of astronomy. Commission } \\
46 \text { approved the establishment of a newsletter at the XVIth } \\
\text { General Assembly in Grenoble for this purpose. It is the } \\
\text { intention to issue the newsletter twice per year in June } \\
\text { and December in the eight page format of this first issue. } \\
\text { It is our editorial policy to publish short (say } 1-2 \text { page) } \\
\text { articles, letters, puzzles, cartoons or any topic which } \\
\text { bears directly on the joint interests of the commission - } \\
\text { ASTRONOMY and EDUCATION. } \\
\text { If you have experiences, worthy of record, in the } \\
\text { teaching of astronomy at university, secondary school, } \\
\text { primary school levels or public education, we shall be glad } \\
\text { to hear from you. We want to know about sucessful and un- } \\
\text { successful astronomical curricula, we want to hear about } \\
\text { sad or funny situations which develop in teaching astronomy. } \\
\text { If you have just written a new course, let us hear about it, } \\
\text { its aims and objects. Stir up argument, fan the flames or } \\
\text { damp it down - the sole criterion for acceptance will be: } \\
\text { does the contribution add to the discussion of how astronomy } \\
\text { should relate to teaching and how teaching should relate to } \\
\text { astronomy. }\end{array}$ \\
\hline
\end{tabular}

Figure 1. Cover of NL1.

The International School for Young Astronomers (ISYA) is a project of the IAU, established in 1967. The objective of ISYAs is to broaden the participants' perspective on astronomy by lectures from an international faculty on selected topics of astronomy, seminars, practical exercises and observations, and exchange of experiences. Many ISYAs were mentioned and reported in the NLs (Table 2) and the NL78 (2013) even published pictures.

The Visiting Lecturers Program (VLP), as was the case for the ISYA, supported the professional training of astronomers with a series of courses. Later, VLP became the 


\begin{tabular}{|c|c|}
\hline \multicolumn{2}{|c|}{$\begin{array}{c}\text { INTERNATIONAL ASTRONOMICAL UNION } \\
\text { COMMISSION } 46 \text { - TEACHING OF ASTRONOMY } \\
\text { NEWSLETTER }\end{array}$} \\
\hline $\begin{array}{l}\text { President: } \\
\text { L. Houziaux } \\
\text { Institut d'Astrophysique } \\
\text { Université de Liege } \\
\text { Avenue de Cointe } 5 \\
4200 \text { Cointe-Ougree } \\
\text { Belgium } \\
\text { Vice-Presidents: } \\
\text { M. Rigutti } \\
\text { C. Iwaniszewska } \\
\text { Organizing Committee: } \\
\text { J. Kleczek } \\
\text { D. McNally } \\
\text { D. Wentzel } \\
\text { E. Kononovich } \\
\text { M. Gerbaldi } \\
\text { R. Robbins } \\
\text { S. Okoye } \\
\text { S. Ferraz-Mello } \\
\text { A. Sandqvist } \\
\text { Editor: } \\
\text { D. McNally } \\
\text { University of London } \\
\text { Observatory } \\
\text { Mill Hill Park } \\
\text { London NW7 2QS } \\
\text { United Kingdom } \\
\text { Printing and Distribution: } \\
\text { Astronomy Program } \\
\text { University of Maryland } \\
\text { College Park } \\
\text { MD 20742 U.S.A. }\end{array}$ & $\begin{array}{l}\text { Number 18, part 1, May } 1985 \\
\text { ASTRONOMY EDUCATION - NATIONAL REPORTS } \\
\text { Sixth Report on the } \\
\text { Development and Present State of } \\
\text { Astronomy Education in Different Countries } \\
1982 \text { - } 1985 \\
\text { Prepared for the XIX IAU General Assembly } \\
\text { New Delhi, India, November } 1985 \\
\text { Table of contents: Reports from } \\
1 \text { Australia } \\
2 \text { Belgium } \\
3 \text { Canada } \\
5 \text { Colombia } \\
6 \text { Egypt } \\
7 \text { Finland } \\
11 \text { France } \\
12 \text { German Democratic Republic } \\
13 \text { German Federal Republic } \\
14 \text { India } \\
16 \text { Japan } \\
17 \text { Paraguay } \\
18 \text { Peru } \\
19 \text { Poland } \\
21 \text { Portugal } \\
22 \text { South Africa } \\
26 \text { Spain } \\
29 \text { U. S. S. R. } \\
32 \text { U. K. } \\
35 \text { U. S. A. }\end{array}$ \\
\hline $\begin{array}{l}\text { These re } \\
\text { astronom } \\
\text { in count } \\
\text { persuasi } \\
\text { to devel } \\
\text { to convi } \\
\text { of astro }\end{array}$ & $\begin{array}{l}\text { itiative of astronomers in countries both } \\
\text { and struggling to make a start in astronomy, } \\
\text { erent educational systems and political } \\
\text { should be useful to any astronomers anxious } \\
\text { ation in their countries. They may be useful } \\
\text { astronomy education and proposed methods } \\
\text { both important and practical. } \\
\text { atzel and L. Houziaux, } \\
\text { rs, part } 1 \text { of this newsletter }\end{array}$ \\
\hline
\end{tabular}

Figure 2. Cover of NL18.

Working Group for the Worldwide Development of Astronomy, which published some Newsletters written by Alan H. Batten (NL33, 1991; NL38, 1993, NL48, 1998). After this, the Program Group for the World-wide Development of Astronomy (PGWWDA) published the reports of many travels, such as the examples of John Hearnshaw in Mongolia (NL61, 2004), Thailand and Laos (NL66, 2007) and John Hearnshaw with Julieta Fierro in Cuba (NL62, 2005).

The National Reports, named also Triennial Reports of the National Representatives or National Liaisons, were published in relation to the IAU General Assemblies (GA) and sometimes as a special edition of the NL. They showed projects and activities in 


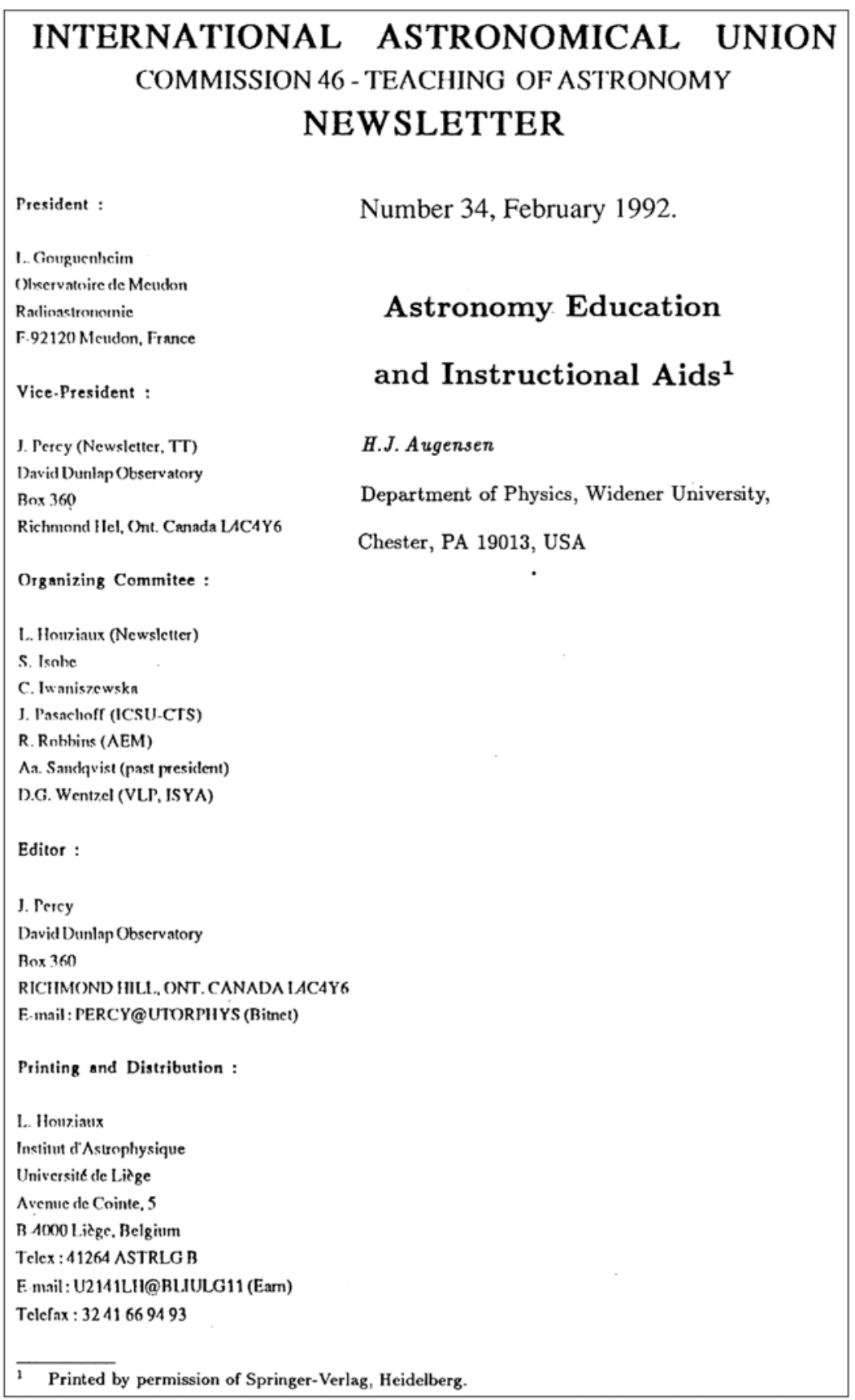

Figure 3. Cover of NL34.

many countries with a format and that included the different school levels, such as: General Information, Primary Schools, Secondary Schools, University Education and Public Education. Some published reports are:

- NL11, 1982: Fifth Report on the Development and the Present State of Astronomy Education in Different Countries (1979-1982);

- NL18, 1985: Sixth Report on the Development and the Present State of Astronomy Education in Different Countries (1982-1985); 


\section{NEWSLETTER}

\section{IAU COMMISSION 46: THE TEACHING OF ASTRONOMY}

President: Lucienne Gouguenheim

Radioastronomie, Observatoire de Paris-Meudon, F-92195 Meudon Cedex, France Electronic Mail: GOUGUENH@FRMEU51

Vice-President and Newsletter Editor: John R. Percy

Erindale Campus, University of Toronto, Mississauga, Ontario LSL 1C6, Canada Electronic Mail: PERCY@UTORPHYS.BITNET

Organizing Committee: J. Fierro, M. Gerbaldi, L. Houziaux, S. Isobe, C. Iwaniszewska, J. Pasachoff, R. Robbins, Aa. Sandqvist, D. Wentzel

Issue \# 36; February, 1993

\section{EDITORIAL - LINKING SCIENCE EDUCATION AND RESEARCH}

Research and discovery are the essence of science, and the reason why science is so satisfying to do and to teach. Can students and the general public experience the excitement of research and discovery by participating actively in it? Not if science is perceived as big, expensive, complex or highly technical. "Small science", however, can be relevant and accessible, especially in the developing countries.

In Canada, students can experience research and discovery through science fairs or science "Olympics", though the structure and competitive environment of these does not accurately reflect science as a career. The Youth Science Academy [196 Carlton St., Toronto, Canada M5A 2K8], founded in 1989, exposes students to science and scientists through field trips and seminars. The activities are planned by a council of students from in and around Toronto; this is the strength of the organization. Its members do not actually do science as part of its activities. In Ontario, high school students carry out "independent study units" as part of all advanced courses. Occasionally, they may work in a scientific environment as part of a cooperative education arrangement. About 150 of the most fortunate ones are accepted into the University of Toronto Mentorship Program [c/o Faculty of Arts and Science, University of Toronto, Toronto, Canada M5S 1A1; see paper by Percy 1990, JRASC 84, 49], in which they can work on research projects with university faculty members. Because this program is intensive and therefore limited in size, it would make sense to develop a program in which mentor scientists met with a group of students (such as a class) and their teacher at the beginning of a term, to discuss the design and methodology of an original group project. The students could then work on their parts of the project, consulting the mentor, if necessary, by mail, phone or e-mail. The mentor could then meet with the group at the end of the term to discuss the analysis and interpretation of the results. These could then be presented orally or as posters at a city-wide "science academy" conference.

What kind of projects would be original, interesting and useful? Perhaps those involving monitoring with simple, standardized instruments; long-term or comparative studies of, for instance, the health and/or pollution of environments such as lakes and rivers; studies of large populations of individuals

Figure 4. Cover of NL36.

- NL24A, 1988: Sixth Report on the Development and the Present State of Astronomy Education in Different Countries (1985-1987);

- NL31, 1991: National Reports (1988-1990);

- NL37, 1993: National Reports (1990-1993);

- NL45, 1997: Triennial National Reports (1993-1996);

- NL51, 1999; NL52, 2000: Triennial Reports (1996-1998);

- Newsletter Supplement National Liaison Triennial Reports 2002, and

- NL82, 2015: Final Reports from National Liasons.

As for the Astronomy Educational Materials, many things were published, but frequently as a Special Edition named as an Addendum, with material in English, French and Spanish. There was even a Special Edition (NL34, 1992) named Astronomy Education and Instructional Aids (Fig. 3).

Many Meetings were advertised and reported. Specially the IAU GAs with Education Sessions and Business Meetings were shown as: NL13, 1983; NL53, 2000; NL59, 2003 and NL65, 2006.

Other stories about meetings on education were for example: GIREP Conference 1987 (NL21, 1987), IAU Colloquium 105 (NL22, 1987), IAU Colloquium 162 (NL41, 1995), IX LIADA Convention (NL57, 2002), Astronomy Education Alliance Meeting (NL80, 2014) and International Symposium on Education in Astronomy and Astrobiology (NL86, 2017). 


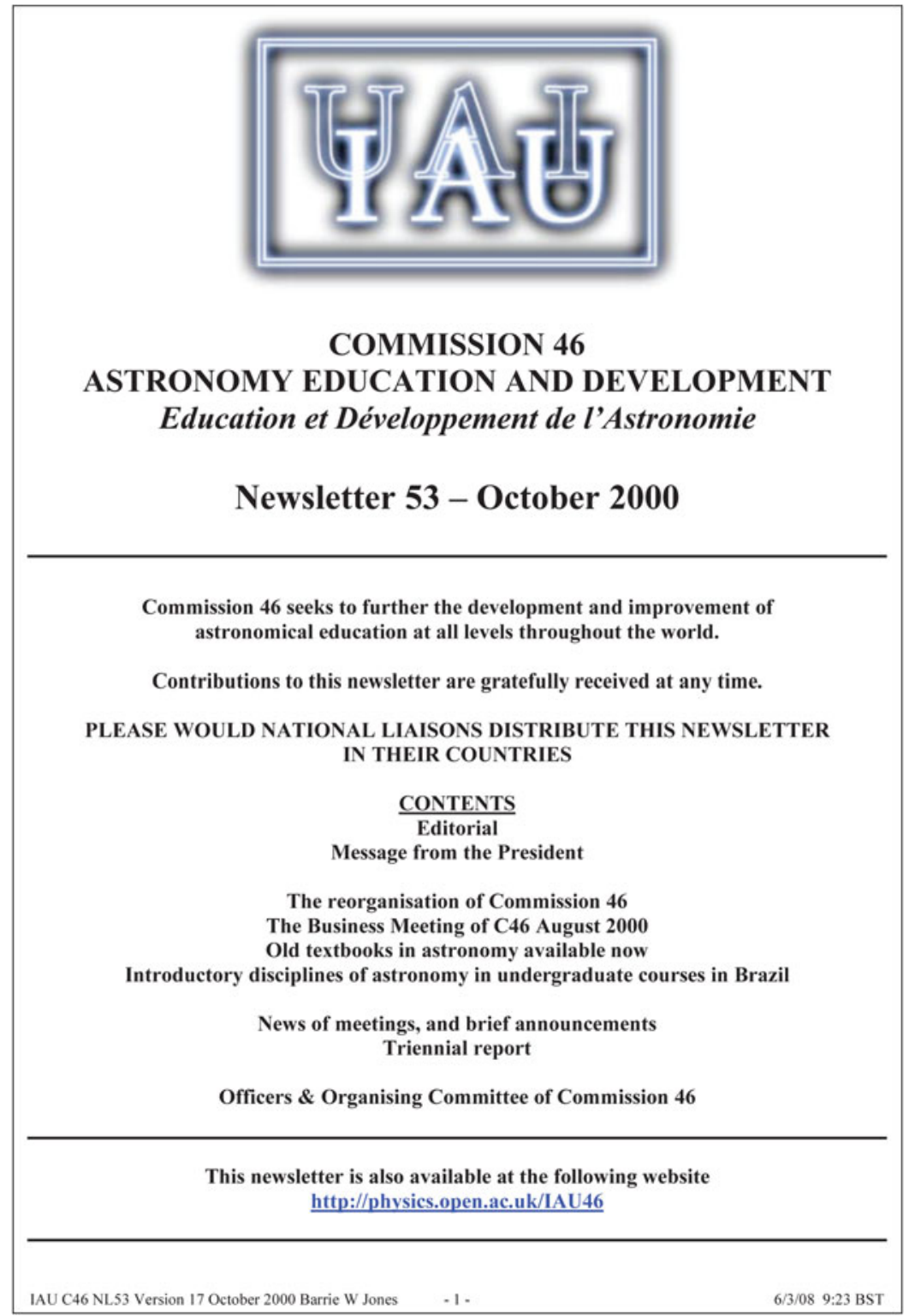

Figure 5. Cover of NL53.

Important Courses for Astronomy Teaching and Education were advertised and reported, such as: European Association for Astronomy Education (EAAE) International Summer School (NL50, 1999).

Many solar eclipses and other phenomena were reported such as: The 11 August 1999 total solar eclipse, J.M. Pasachoff (NL50, 1999), (NL51, 1999); Report from PG 'Solar Eclipses' J.M. Pasachoff (NL55, 2001); Transit of Venus, B. Jones (NL61, 2004) and the American Eclipse of 2017, J.M. Pasachoff (NL86, 2017).

Occasionally, papers dealing with great education questions and subjects were published, such as:

- Why astronomy is useful?, NL55, Jones;

- Why astronomy should be taught in schools?, NL55, Jones; 
- Student cognition and effective astronomy instruction, NL7, Robbins, Cooper;

- Astronomy education and the future of human needs, NL16, Shengyun;

- Astronomical misconceptions, NL36, Lutz;

- Computing in education, NL8, McNally;

- Piaget in New Mexico: a cultural divide, NL8, Zeilik.

Appendix 1 shows published papers in the NL. This list does not pretend to be complete, and it is given as a main guide only. We apologize for any omissions.

Many times, only abstracts were published or even a preprint of a paper published in other journals. All these papers should be used as references for the area. Often this represents a short cut or a representative contribution for a major theme of its time, and often too it was as a classical discussion that serves as a permanent record and which is also suitable for current discussions on astronomy education issues.

In addition, when it comes to published papers, the NL has advertised the publications of many issues of the journals, such as Astronomy Education Review (AER) and the Latin-American Journal of Astronomy Education (RELEA) (NL73, 2010).

Some Projects and important Issues were published as: 'Project STAR - Science Teaching Through its Astronomical Roots', (NL22, 1987); 'New Approaches to Education for the Public - Planetaria' (NL41, 1995); 'The Faulkes Telescope Project' (NL63, 2005); ASTRONET (NL68, 2008) and 'Telescopes for schools' (NL72, 2010).

Specifically, the issue on Light Pollution, can be found as: 'About Light Pollution' (NL40, 1994) from the Commission 50 working group on controlling light pollution (NL54, 2001), Also we have the 'Global Astronomy Month's "Dark Skies Awareness" Programs for April, 2014: Three Activities of Interest' (NL79, 2014).

The issue of Women in Astronomy was first published in the contribution: 'A status of the women in astronomy in different parts of the world', and was compiled by J.R. Percy (NL10, 1981). There were published references about North America and later papers about women astronomers in France (L. Gouguenheim), Poland (C. Iwaniszewska), USA (C. Pilachowski), USSR (E. Kononovich). The papers 'Women worldwide in astronomy', D. Hunter and V. Rubin (NL28, 1989), the 'Resource Guide on Women in Astronomy', A. Fraknoi, (NL69, 2008) and the '2010 Calendar: Women Astronomers who made history', B. Jones, (NL72, 2010) contributed to this lively issue.

New Technologies were mentioned in each period as innovations concerning teaching materials and resources were developed, such as:

- Astronomical Slides (NL7, 1980);

- Movies and Computing (NL8, 1980);

- Video Disc (NL10, 1981);

- Computers/television (NL13, 1983);

- Microcomputers (NL16, 1984);

- Microcomputer telescope (NL19, 1986);

- Slide set: The Heavens on tape (NL29, 1990);

- Slides (NL35, 1993);

- IMAX (NL44B, 1996);

- Astronomy on line: Robotic Telescope (NL46, 1997);

- ESA CDOM (NL59, 2003);

- Audio Recording (NL68, 2008);

- PBS Television (NL71, 2009);

- Classroom Powerpoints available in Spanish (NL76, 2012);

- Open Online Astronomy Class (78, 2013).

Many of these were published by Andrew Fraknoi as an advertisement for the Astronomical Society of Pacific resources. 
In the Digital Era, the publication format was changed and this can be seen in: 'This Newsletter goes electronic' (NL40, 1994); 'IAU on the WWW' (NL42B, 1996) and 'IAU Commission 46 Website' (44B, 1997).

The International Year of Astronomy and the IAU Decadal Strategic Plan For Astronomy Development were addressed (NL68, 2008).

New Projects were announced, advertised and reported such as: UNAWE (NL68, 2008) and Ten years (NL84, 2016) and GALILEOSCOPE (NL76, 2012). As for the IAU Office of Astronomy for Development (OAD) updates were published (NL76, 78, 79, 81, 83). Even reports of International Astronomy Olympiads were published (NL72, 74, 79).

A series of informative book reviews written, mainly by Naomi Pasachoff, and were published from N71, 2009 to NL87, 2018.

More recently, the New Structure of the Commission was published as: 'C46 - Div. C: From Program Groups to Working Groups' (NL78, 2013) and 'News on the submission to keep C46 as a Commission in the new IAU structure' (NL80, 2014).

After that, NL82 (2015) was considered the last issue under the previous division structure, as explicitly stated in the text: 'This is the final Newsletter of Commission 46, so no further contributions are solicited'.

Nevertheless, the recent WG reports were published as: NASE: Network for Astronomy School Education (NL 73, 75, 76, 77, 81, 83, 84, 87); WG3 on Equity and Inclusion and Intercommission; WG B7\&C1:Dark Skies Challenge and Education (NL84, 2016); WG Theory and Methods in Astronomy Education (NL85, 2017) after that "last" issue.

More recently, 'Inspiring Stars - The IAU Inclusive World Exhibition Project Report' (NL87, 2018) has been published.

During the years of NL publication, calls to solicit contributions had to be made, for example: 'An Appeal for Contributions' (NL33, 1991).

Finally, so that readers would know about the names of those who spent many efforts over the decades on the publication of the Newsletters, including presidents of the Commission and NL editors, pictures can be seen in: NL63, 2005; NL65, 2006; NL78, 2013; NL76, 2012.

\section{Conclusions}

Considering what we have surveyed and analyzed, some general considerations can be made.

Concerning the archives and documents, the files are an important repository of for Commission 46 and for the present C1. To gather (almost all) the NL and make them available is important, because they had been at risk of being lost.

However, we continue to search for the issues: N.12 (July 1982), 23, 24, 24B and 25 (between 1987 and 1988). So, we ask for the help of colleagues to search in their archives or institutions to get the missing issues and to complete the survey of the collection. Certainly it is related to the Resolution B3, proposed in the XXXth IAU GA on preservation, digitization and scientific exploration of historical astronomical data.

From these issues the intentions, efforts and dedication of the editors, Presidents, Vicepresidents, members of the organizing committee, those people responsible for printing and distribution of the NL, National representatives/Liaisons and authors were seen clearly and distinctly.

The preliminary look at the published NL showed many projects, reports, meetings, courses, teaching materials, papers etc.

With a more historical approach, probably trends and gaps still to be found would be revealed, by using a content analysis. Considering the efforts, actions and projects over about 40 years, a deeper study should show what has been achieved and what is still to be done and where more actions are necessary. 
The reader may notice that there is a large diversity of activities, but also a lack of systematic evaluation. Even within a diversity of actions and projects, sometimes they look very diverse, and may lack coherence or guidelines. To be sure, this latter action was not a duty of the officers of commission and NL editors, but future studies should provide such an analysis, which may serve as a gauge for the many important achievements of the Commission.

The past efforts which have been undertaken must be considered as a part of the legacy of the area by educators, researchers and practitioners, and especially by the newcomers to the field when applying for new proposals and projects. This should not be regarded as a constraint, but rather a question about how past experiences are useful to face the new times and future perspectives.

There is also the question of the evolution of the NL itself: in the digital era with the Internet, blogs, MOOCs and so many resources, how should we consider the importance of maintaining the Newsletters? This is quite a challenge, but as an initial answer, may be it is important to keep the regular publication of the Newsletters and to search for new technologies by all the people throughout the world. In particular, they may aim initially for information as IAU members, and then they will want to contribute to the formation of the community that is yet incipient in their countries.

Many beautiful messages from the presidents and editors expressing the enthusiasm and the power of the works of the members of the Commission can be found. As an example, it is mentioned here a text, Message from the President, written by Julieta Fierro:

"... I would like to acknowledge all the fine work that has been carried out by the members of our Commission, in particular by the Organising Committee. I shall end this message with a few personal comments on education. I believe there are no general rules for good astronomy teaching. Not only every culture, but each classroom has its own particularities. Nevertheless a few guidelines for good teaching can be mentioned that have been useful for many educators throughout the world, and that are much to do with emotions.

1. Acknowledgement...;

2. Joint participation...;

3. Special agreeable experiences...;

4. Agreeable physical contact...;

5. Cooperation...;

6. Shared creativity...;

7. Shared success...;

8. Telling about one's own experience...;

9. External contrast...

As can be seen, astronomy teaching has a lot to do with love and with giving." (Fierro 2000)

Finally, in the Newsletters there are many published contributions that show the participation of many members from many countries and the efforts to improve the astronomy education through the world.

\section{Discussion}

Ros: Just a suggestion. Could you show again the numbers of News Letters from Commission 46 that you did not find? I believe that some of us could try to help you.

BREtones: The numbers are 12, 23, 24B and 25. 
HeARnSHAW: OAE may decide to have a journal for astronomy education (just like OAO's CAP journal). What do you think about this proposal?

Bretones: Yes. This is one of the main goals of the Commission $\mathrm{C} 1$ for the next term. The main goals are: the journal, and a meeting like CAP. Thank you!

\section{Acknowledgements}

I would like to express my deepest thanks to Jorge E. Horvath for his suggestions. I also thank the IAU and FAPESP for the travel grants and financial support [grant 2018/07912-9, Sao Paulo Research Foundation (FAPESP)].

\section{References}

Fierro, J. 2000 IAU Newsletter 52

Gerbaldi, M. 1990, in J. M. Pasachoff \& J. R. Percy (eds.), The Teaching of Astronomy (Cambridge: Cambridge University Press), p. 227

Isobe, S. 2005, in J. M. Pasachoff \& J. R. Percy (eds.), Teaching and Learning Astronomy (Cambridge: Cambridge University Press), p. 249

Wentzel, D. G. 1990a, in J. M. Pasachoff \& J. R. Percy (eds.), The Teaching of Astronomy (Cambridge: Cambridge University Press), p. 1

Wentzel, D. G. 1990b, in J. M. Pasachoff \& J. R. Percy (eds.), The Teaching of Astronomy (Cambridge: Cambridge University Press), p. 405

\section{Appendix 1. Some papers on Astronomy Education in the IAU NLs}

\begin{tabular}{|c|c|c|c|}
\hline Title & Author(s) & NL & Year \\
\hline An Introductory course in Astronomy & D. McNally & 1 & 1977 \\
\hline The case of teaching astronomy & D. McNally & 2 & 1977 \\
\hline Astronomy Education in Primary School & J.E. Bishop & 2 & 1977 \\
\hline Student Reasoning ability and astronomy teaching & D. Schatz & 3 & 1978 \\
\hline $\begin{array}{l}\text { The Effect of the Committee of Ten Report on U.S. } \\
\text { Astronomy Education }\end{array}$ & J.E. Bishop & 3 & 1978 \\
\hline Elementary Astronomy & L. Pujol & 4 & 1979 \\
\hline Student cognition and effective astronomy instruction & R.R. Robbins \& R.G. Cooper & 7 & 1980 \\
\hline Experiments in Astronomy Lessons & J. Domansky & 7 & 1980 \\
\hline Computing in education & D. McNally & 8 & 1980 \\
\hline Piaget in New Mexico: a cultural divide & M. Zeilik & 8 & 1980 \\
\hline Astronomy and the microcomputer in rural U.S. & E.Q. Carr & 9 & 1991 \\
\hline Astronomy as a vehicle for motivation in science education & P.A. Stahl & 9 & 1981 \\
\hline Class Character & D. McNally & 11 & 1982 \\
\hline Training of Astronomy Teachers & C. Iwaniszewska & 13 & 1983 \\
\hline $\begin{array}{l}\text { Astronomy Teaching in Physics, Chemistry, Mathematics } \\
\text { and Biology }\end{array}$ & J. Kleczek & 13 & 1983 \\
\hline The Project & D. McNally & 14 & 1983 \\
\hline $\begin{array}{l}\text { Advanced Projects in astronomy for undergraduates using } \\
\text { film copies of UKST Photographs }\end{array}$ & M.T. Brück & 15 & 1984 \\
\hline Microcomputers in Astronomy & E. Grayzeck & 16 & 1984 \\
\hline Astronomy education and the Future human needs & D. Shengyun & 16 & 1984 \\
\hline A travelling observatory? & D. McNally & 17 & 1985 \\
\hline A travelling telescope & D. McNally \& R.M. West & 19 & 1986 \\
\hline Antarctica - a lesson to be learned & M. Othman & 19 & 1986 \\
\hline Radio astronomy for undergraduates & J.L. Safko \& R.F. Whitesell & 19 & 1986 \\
\hline $\begin{array}{l}\text { A micro-computer telescope simulator for university } \\
\text { teaching }\end{array}$ & D.J. Adams \& D.J. Raine & 19 & 1986 \\
\hline High technology at smaller observatories & R.M. Genet & 19 & 1986 \\
\hline Reaching the Public & R. Carlberg & 20 & 1986 \\
\hline Variable stars and the teaching astronomy & J.R. Percy & 20 & 1986 \\
\hline Telescopes for students & R.L. Bishop & 21 & 1987 \\
\hline Puppets and Astronomy & H.L. Tignanelli & 21 & 1987 \\
\hline
\end{tabular}




\begin{tabular}{|c|c|c|c|}
\hline Title & Author(s) & NL & Year \\
\hline $\begin{array}{l}\text { GIREP Conference } 1986 \text { - Cosmos, an educational } \\
\text { Challenge }\end{array}$ & K. Kortland & 21 & 1987 \\
\hline Alternative frameworks and the teaching of Astronomy & J.H. Baxter & 21 & 1987 \\
\hline Women Worldwide in Astronomy & D. Hunter \& V. Rubin & 28 & 1989 \\
\hline Determination of the obliquity of the ecliptic & R.M. Ros \& M.J. Llinas & 28 & 1989 \\
\hline The IAU and Global Change & D. McNally & 30 & 1990 \\
\hline Basic Science in the Developing World & D.G. Wentzel & 35 & 1992 \\
\hline On the educational role of Astronomy & C. Iwaniszewska & 35 & 1992 \\
\hline Algol, changing spirit & R.M. Ros-Ferré \& E. Viñuales-Gavín & 35 & 1992 \\
\hline Astronomical Misconceptions & T. Lutz & 36 & 1993 \\
\hline The Solar System and our region & T.C. Surroca \& J.P. Pujol & 38 & 1993 \\
\hline Education in Astronomy: An International Perspective & J. R. Percy & 39 & 1994 \\
\hline Using Computers to personalize a large class & R.R. Robbins & 41 & 1995 \\
\hline New approaches to Educating the public - Planetaria & N. Raghavan & 41 & 1995 \\
\hline A simple method to determining star magnitudes & S. Bhagat & 49 & 1998 \\
\hline Healthy Graduate ignorance & D. McNally & 50 & 1999 \\
\hline $\begin{array}{l}\text { Introductory disciplines of astronomy in undergraduate } \\
\text { courses in Brazil }\end{array}$ & P.S. Bretones & 53 & 2000 \\
\hline Astronomy Developments strategies and the IAU & J. Andersen & 54 & 2001 \\
\hline $\begin{array}{l}\text { Major dynamical, physical, and technological concepts of } \\
\text { space science }\end{array}$ & M. Melek \& C.P. Celebre & 54 & 2001 \\
\hline Why astronomy is useful? & B.W. Jones & 55 & 2001 \\
\hline Why astronomy should be taught in schools - Resolution & B.W. Jones & 55 & 2001 \\
\hline $\begin{array}{l}\text { Robotic observatories in e-education and e-research } \\
\text { (ROER) }\end{array}$ & I. Tasker & 62 & 2005 \\
\hline A life in astronomy education & D. McNally & 71 & 2009 \\
\hline $\begin{array}{l}\text { A new dark sky reserve for the central south island of } \\
\text { New Zealand }\end{array}$ & J. Hearnshaw & 77 & 2013 \\
\hline A massive open online astronomy class & C. Impey & 78 & 2013 \\
\hline $\begin{array}{l}\text { Gaming to learn astronomy, an innovative approach, two } \\
\text { study cases }\end{array}$ & M. Metaxa & 86 & 2017 \\
\hline Where is NASA's New Horizons going next & J. Pasachoff & 86 & 2017 \\
\hline $\begin{array}{l}\text { A century of astronomy and communication without } \\
\text { boundaries }\end{array}$ & M. Stavinschi & 87 & 2018 \\
\hline $\begin{array}{l}\text { Ephemerides: Gauss, Gould and the Argentine National } \\
\text { Observatory }\end{array}$ & S. Paolantonio & 87 & 2018 \\
\hline
\end{tabular}

